\title{
RELATIVE HUMIDITY AND ITS INTERACTION WITH THE WOUNDS ON DECAY INCIDENCE AND RIPENING OF 'GALAXY' APPLES DURING COLD STORAGE
}

\author{
UMIDADE RELATIVA E SUA INTERAÇÃO COM FERIMENTOS SOBRE A \\ INCIDENCIA DE PODRIDÕES E O AMADURECIMENTO DE MAÇÃS 'GALAXY' \\ DURANTE O ARMAZENAMENTO
}

\author{
Auri BRACKMANN'; Fabio Rodrigo THEWES ${ }^{2}$; Rogério de Oliveira ANESE; \\ Eduardo Perkovski MACHADO ${ }^{4}$; Vagner LUDWIG ${ }^{4}$; Erani Eliseu SCHULTZ ${ }^{2}$ \\ 1. Professor, Doutor, Universidade Federal de Santa Maria - UFSM, Santa Maria, RS, Brasil; 2. Mestrando em Agronomia - UFSM, \\ Santa Maria, RS, Brasil; 3. Professor, Doutorando, Instituto Federal de Santa Catarina - Campus Urupema; 4. Graduandos em \\ Agronomia - UFSM, Santa Maria, RS, Brasil;
}

\begin{abstract}
The objectives of the present work were control the decay incidence and ripening of wounded fruits by the relative humidity management during the storage. Fruits were allocated in mini experimental chambers at the temperature of $1{ }^{\circ} \mathrm{C}$ during 5 months. Was verified a significant interaction on ethylene production after 2 and 6 days of shelf life at $20^{\circ} \mathrm{C}$. On the evaluation carried out after 6 days, wounded fruits stored under LRH showed lower ethylene production. There was higher mass loss in wounded fruits stored in HRH. Wounded fruits showed high decay incidence. The LRH is not an efficient method to control decay incidence in wounded fruits, but maintain higher flesh firmness, lower ethylene production and respiration rate.
\end{abstract}

KEYWORDS: Malus domestica. Decay severity. Physiological disorders. Mass loss. Ethylene.

\section{INTRODUCTION}

'Galaxy' apple is a spontaneous strain of 'Gala', it show high commercial acceptance, either at national or international market, especially due to the high red color index of its epidermis. The harvest period of this strain is relatively short and is carried out manually, where could occur wounds on the fruits, especially due to the wounds caused by the nails, fruit peduncle and also by package that show irregular surface (MATTIUZ; DURIGAN, 2001). Berton (2010) reports that the bitter decay and Colletotrichum mound growth, has relation with the wounded caused by fruit fly. This damage may be increase the decay incidence, physiological disorders, ethylene production and respiration rate that affecting the fruit ripening.

Mechanical wounds may be origin physiological disorders and accelerate the fruit ripening by the ethylene production rise (STEFFENS et al., 2008), that is a plant hormone involved on fruit ripening (ALVES et al., 2010). The mechanical wound originated by impact, could result in epidermis wound and expose the cellular juice (MATTIUZ; DURIGAN, 2001; DURIGAN et al., 2005; DE MARTINO et al., 2006; ALVES et al, 2010), occurring phenolic compound oxidation (STEFFENS et al., 2008), and thus, flesh browning, higher ethylene production (STEFFENS et al., 2008; ALVES et al., 2010) and increase respiration rate
(MATTIUZ; DURIGAN, 2001) and so decrease fruit quality during postharvest.

Cold storage consists in temperature and relative humidity control, which delay ripening and so increase the storage period. According Brackmann et al. (2005), apples stored under low relative humidity (LRH) showed lower pulp cracking and decay incidence in relation to high relative humidity (HRH). Brackmann et al. (2008) observed lower decay incidence in 'montenegrina' mandarin stored under LRH. Some works suggest that LRH decrease the incidence of physiological disorders (BRACKMANN et al., 2007; ALVES et al. 2009; WEBER et al., 2012). However, nowadays there is a lack of information evaluating the interaction of relative humidity and wounded fruits during the storage. In view of this, the objectives of the present work were control the decay incidence and ripening of wounded fruits by the relative humidity management during the storage.

\section{MATERIAL AND METHODS}

The experiment was carried out at the Postharvest Research Center of the Plant Science Department of the Federal University of Santa Maria, during the year of 2013. The plant material was composed by 'Galaxy' apples, originated from a commercial orchard located in Vacaria, RS, Brazil. After harvest, fruit were transported to the 
Postharvest Research Center, where a selection was carried out, aiming eliminate fruits with any type of lesion due to the transportation. In order to simulated the wound, was used a needle with $3 \mathrm{~mm}$ of diameter and $5 \mathrm{~mm}$ of length, introduced in two opposite sides of the equatorial region of fruits. Immediately after the wound, fruits where put into mini experimental chamber with $0.233 \mathrm{~m}^{3}$ at the temperature of $1^{\circ} \mathrm{C}$ during 5 months. During the 5 months, the relative humidity was monitored weekly, by a psychrometer installed inside each mini chamber. The LRH was maintained at $94 \%$ $( \pm 1 \%)$ with the use of calcium chloride, that allowed absorb the humidity of the air presented in the chamber, when it was higher the pre-established level. The HRH $(98 \%)( \pm 1 \%)$ was obtained by closing the chamber without calcium chloride. The temperature of the chambers was monitored daily during the storage period. The statistical scheme used on the experiment was completely randomized, with five replicates of 50 fruit each. The experiment was conducted in a factorial scheme $(2 \times 2)$, evaluating the interaction of wounded and not wounded fruits; stored under high relative humidity (HRH) (98\%) and low relative humidity (LRH) $(94 \%)$.

After 5 months of storage, ethylene production and respiration rate were evaluated at chamber opening, 2, 4 and 6 days of shelf life at $20^{\circ} \mathrm{C}$. Already, the mass loss, flesh firmness, flesh browning, mealiness, decay incidence and severity, soluble solids and titratable acidity were evaluated only after 6 days of shelf life. The ethylene production and respiration rate was obtained according Weber et al. (2012). The mass loss was determined by weighting the fruits before and after storage, data expressed in percentage of initial mass. Mealiness incidence was evaluated by counting the fruits that sowed a pulp with low succulence, result showed in percentage. Flesh firmness was obtained by the introduction of a penetrometer $(11.0 \mathrm{~mm})$ in two opposite sides of the equatorial region of fruit, where previously the epidermis was removed, data expressed in Newton $(\mathrm{N})$. Flesh breakdown and decay incidence were evaluated by counting the fruit that presented any symptom of it disturbs and expressed in percentage of total fruit. Decay severity: assessed subjectively through the identification of the area affected by decay, according to a scale of $0-3: 0=0 \%$ of the fruit area with decay; $1=0$ up to $30 \%$ of the fruit area with decay; $2=30$ up to $70 \%$ of the fruit area with decay; $3=70$ up to $100 \%$ of the fruit area with decay. The average was obtained by the total number of fruit multiplied by their respective decay level, this product was then divided by the total number of fruit in the sample. Soluble solids were determined by refractometry and expressed in ${ }^{\circ}$ Brix. Titratable acidity determined by titration of a solution containing $10 \mathrm{~mL}$ of juice diluted in $100 \mathrm{~mL}$ of distillated water, with $\mathrm{NaOH} 0,1 \mathrm{~N}$, results were expressed in $\mathrm{mEq} 100 \mathrm{~mL}^{-1}$.

A variance analysis (ANOVA) was conducted to each characteristic evaluated, the averages being submitted to the Tukey test with a $5 \%$ error probability $(\mathrm{p}<0.05)$. The data expressed in percentage were transformed with the arc.sin $\left((\mathrm{x} / 100)^{0,5}\right)$ formula before being submitted to the variance analysis.

\section{RESULTS AND DISCUSSION}

At chamber opening, fruits without wounds showed lower ethylene production, independently of the relative humidity adopted during the storage (Table 1). However, after two days of shelf life, was verified lower ethylene production only on fruits without wounds and stored under LRH. After four days of shelf life, either fruit with or without wound, stored under LRH showed lower ethylene production, corroborating results obtained by Brackmann et al. (2007) and Weber et al. (2012), that also observed lower ethylene production in apples stored under LRH. The lower ethylene production may be a function of the $\mathrm{LRH}$ and storage temperature $\left(1^{\circ} \mathrm{C}\right)$ adopted, once on this temperature is a lower ACC oxidase enzyme activity (WEBER et al., 2012), that is responsible of the last step of ethylene biosynthesis. After six days of shelf life, wounded fruits, stored under LRH again showed lower ethylene production.

In relation to respiration rate, at chamber opening was not verified significant effect of wounds and relative humidity, but after two days of shelf life, fruits submitted to LRH showed lower respiration rate (Table 2). In 'Gala' apples, STEFFENS et al. (2008) not found significant increment of respiration rate when fruits were submitted to wounds by impact. The same authors attributing that is significant difference among the studies, once the mechanical wound could be varies and there may be are difference among the cultivars. However, other researches founded significant increment in the respiration rate on fruit submitted to mechanical wound by impact, pressure and cut in guava (MATTIUZ; DURIGAN, 2001), acid limes (DURIGAN et al., 2005) and by impact in apples (MONTERO et al., 2011). 
Table 1. Ethylene production of 'Galaxy' apples after five months of cold storage plus six days of shelf life. Santa Maria, Brazil, 2015.

\begin{tabular}{|c|c|c|c|c|c|c|}
\hline \multirow{2}{*}{ Treatments } & \multicolumn{2}{|c|}{$\begin{array}{l}\text { Ethylene production } \\
\left(\mu \mathrm{L} \mathrm{C}{ }_{2} \mathrm{H}_{4} \mathrm{~kg}^{-1} \mathrm{~h}^{-1}\right)\end{array}$} & \multirow{2}{*}{ Mean } & \multicolumn{2}{|c|}{$\begin{array}{l}\text { Ethylene production } \\
\left(\mu \mathrm{L} \mathrm{C} \mathrm{C}_{2} \mathrm{H}_{4} \mathrm{~kg}^{-1} \mathrm{~h}^{-1}\right)\end{array}$} & \multirow{2}{*}{ Mean } \\
\hline & $\begin{array}{l}\text { Without } \\
\text { puncture }\end{array}$ & $\begin{array}{l}\text { With } \\
\text { puncture }\end{array}$ & & Withoutpuncture & $\begin{array}{l}\text { With } \\
\text { Puncture }\end{array}$ & \\
\hline & \multicolumn{2}{|c|}{ Chambers opening } & & \multicolumn{2}{|l|}{2 days shelflife } & \\
\hline RH 98\%* & 36.17 & 45.48 & $40.82 \mathrm{a}$ & $67.80 \mathrm{Aa}$ & 79.34Aa & 73.57 \\
\hline RH $94 \% * *$ & 41.83 & 44.75 & $43.29 \mathrm{a}$ & $49.49 \mathrm{Bb}$ & $80.09 \mathrm{Aa}$ & 64.79 \\
\hline \multirow[t]{2}{*}{ Mean } & $39.00 \mathrm{~B}$ & $45.11 \mathrm{~A}$ & - & 58.64 & 79,71 & - \\
\hline & \multicolumn{2}{|c|}{4 days shelflife } & Mean & 6 days shelflife & & Mean \\
\hline RH $98 \%$ & 135.47 & 161.65 & $148.56 \mathrm{a}$ & $122.46 \mathrm{Ab}$ & 147.18Aa & 134.82 \\
\hline RH $94 \%$ & 131.07 & 101.45 & $116.26 \mathrm{~b}$ & $150.27 \mathrm{Aa}$ & $97.52 \mathrm{Bb}$ & 123.89 \\
\hline Mean & $133.27 \mathrm{~A}$ & $131.55 \mathrm{~A}$ & - & 136.36 & 122.35 & - \\
\hline
\end{tabular}

* UR $98( \pm 1 \%)$ = High Relative Humidity $($ HRH $) * *$ UR $94( \pm 1 \%)=$ Low Relative Humidity (LRH). Means followed by equal letter, lower case in the columns and uppercase in the lines, do not differ by Tukey test, at $5 \%$ of error probability.

Table 2. Respiration rate of 'Galaxy' apples after five months of cold storage plus six days of shelf life. Santa Maria, Brazil, 2015.

\begin{tabular}{|c|c|c|c|c|c|c|}
\hline \multirow{2}{*}{ Treatments } & \multicolumn{2}{|c|}{$\begin{array}{l}\text { Respiration rate } \\
\left(\mathrm{mL} \mathrm{CO}_{2} \mathrm{~kg}^{-1} \mathrm{~h}^{-1}\right)\end{array}$} & \multirow{2}{*}{ Mean } & \multicolumn{2}{|c|}{$\begin{array}{l}\text { Respiration rate } \\
\left(\mathrm{mL} \mathrm{CO} \mathrm{kg}^{-1} \mathrm{~h}^{-1}\right)\end{array}$} & \multirow{2}{*}{ Mean } \\
\hline & $\begin{array}{l}\text { Without } \\
\text { puncture }\end{array}$ & $\begin{array}{c}\text { With } \\
\text { puncture }\end{array}$ & & $\begin{array}{l}\text { Without } \\
\text { puncture }\end{array}$ & $\begin{array}{c}\text { With } \\
\text { puncture }\end{array}$ & \\
\hline & \multicolumn{2}{|c|}{ Chambers opening } & \multicolumn{3}{|c|}{2 days shelflife } & \\
\hline RH $98 \% *$ & 9.84 & 10.42 & $10.13 \mathrm{a}$ & 4.22 & 4.32 & $4.28 \mathrm{a}$ \\
\hline RH 94\%** & 9.03 & 9.08 & $9.06 \mathrm{a}$ & 3.03 & 3.08 & $3.49 \mathrm{~b}$ \\
\hline Mean & $9.43 \mathrm{~A}$ & $9.75 \mathrm{~A}$ & - & $3.63 \mathrm{~A}$ & $3.70 \mathrm{~A}$ & - \\
\hline \multicolumn{3}{|c|}{4 days shelflife } & Mean & 6 days shelflif & & Mean \\
\hline RH 98\% & 4.52 & 4.03 & $4.27 \mathrm{a}$ & 1.93 & 2.13 & $2.03 a$ \\
\hline RH 94* & 3.96 & 3.56 & $3.76 \mathrm{a}$ & 2.13 & 1.94 & $2.04 \mathrm{a}$ \\
\hline Mean & $4.24 \mathrm{~A}$ & $3.79 \mathrm{~A}$ & - & $2.03 \mathrm{~A}$ & $2,04 \mathrm{~A}$ & - \\
\hline
\end{tabular}

* $98( \pm 1 \%)$ = High Relative Humidity $(\mathrm{HRH}) * * 94( \pm 1 \%)=$ Low Relative Humidity (LRH). Means followed by equal letter, lower case in the columns and uppercase in the lines, do not differ by Tukey test, at $5 \%$ of error probability.

There was not observed significant effect of relative humidity and wounds on flesh breakdown incidence (Table 3). Higher mass loss was observed in wounded fruits stored under HRH (Table 3), but there is no significant difference between fruit stored under HRH and LRH. Previously studies also found significant increment in mass loss when acid limes fruits were submitted to wounds by impact, pressure and cut (DURIGAN et al., 2005). In relation to mealiness, was not observed significant effect of wounds, but an important result is that fruit with wounds showed total absence of this disorder
(Table 3). Contrary to mealiness, the flesh firmness was significantly affected by relative humidity, where higher flesh firmness was verified in fruits stored under LRH, independently when fruits were wounded or not wounded. The higher flesh firmness of these fruit can be related to the lower ethylene production by fruit submitted to LRH (BRACKMANN et al., 2007; WEBER et al., 2012). The flesh firmness loss is also related with cell wall components depolymerization, that has close relation with ethylene production (PAYASI et al., 2009). 
Table 3. Mass loss, mealiness, flesh firmness and flesh breakdown of 'Galaxy' apples after five months of cold storage plus six days of shelf life. Santa Maria, Brazil, 2015.

\begin{tabular}{|c|c|c|c|c|c|c|}
\hline \multirow{2}{*}{ Treatments } & \multicolumn{2}{|c|}{$\begin{array}{c}\text { Mass loss } \\
(\%)\end{array}$} & \multirow{2}{*}{ Mean } & \multicolumn{2}{|c|}{$\begin{array}{l}\text { Mealiness } \\
(\%)\end{array}$} & \multirow{2}{*}{ Mean } \\
\hline & $\begin{array}{l}\text { Without } \\
\text { puncture }\end{array}$ & $\begin{array}{l}\text { With } \\
\text { puncture }\end{array}$ & & $\begin{array}{l}\text { Without } \\
\text { puncture }\end{array}$ & $\begin{array}{l}\text { With } \\
\text { puncture }\end{array}$ & \\
\hline RH 98\%* & $0.55 \mathrm{Ba}$ & $6.19 \mathrm{Aa}$ & 3.37 & 8.70 & 0.00 & $4.35 \mathrm{a}$ \\
\hline RH 94\%** & 2.54Aa & 5.07Aa & 3.80 & 3.75 & 0.00 & $1.87 \mathrm{a}$ \\
\hline \multirow[t]{2}{*}{ Mean } & 1.54 & 5.63 & - & $6.23 \mathrm{~A}$ & $0.00 \mathrm{~B}$ & - \\
\hline & \multicolumn{2}{|c|}{$\begin{array}{l}\text { Flesh firmness } \\
(\mathrm{N})\end{array}$} & Mean & \multicolumn{2}{|c|}{$\begin{array}{c}\text { Flesh breakdown } \\
(\%)\end{array}$} & Mean \\
\hline RH 98\% & 51.33 & 51.65 & $51.49 \mathrm{~b}$ & 1.87 & 0.62 & $1.25 \mathrm{a}$ \\
\hline RH 94\% & 57.52 & 58.63 & $58.07 \mathrm{a}$ & 0.62 & 0.00 & $0.31 \mathrm{a}$ \\
\hline Mean & $54.42 \mathrm{~A}$ & $55.14 \mathrm{~A}$ & - & $1.25 \mathrm{~A}$ & $0.31 \mathrm{~A}$ & - \\
\hline
\end{tabular}

* $98( \pm 1 \%)$ = High Relative Humidity (HRH) ** $94( \pm 1 \%)$ = Low Relative Humidity (LRH). Means followed by equal letter, lower case in the columns and uppercase in the lines, do not differ by Tukey test, at $5 \%$ of error probability.

The soluble solids were not affected by the wounds and the relative humidity (Table 4). STEFFENS et al. (2008) also not found significant difference in soluble solids when apples were submitted to wounds by impact. In relation to titratable acidity, wounded fruit showed a significant reduction as compared to fruits without wounds, independently of the relative humidity employed during storage (Table 4). In tomatoes wounded by impact (MORETTI et al., 1998) and guavas (MATTIUZ; DURIGAN, 2001) injured by impact, pressure and cut also occurred a significant reduction in titratable acidity.

Table 4. Decay incidence, decay severity, soluble solids and titratable acidity of 'Galaxy' apples after five months of cold storage plus six days of shelf life. Santa Maria, Brazil, 2015.

\begin{tabular}{|c|c|c|c|c|c|c|}
\hline \multirow{2}{*}{ Treatments } & \multicolumn{2}{|c|}{$\begin{array}{c}\text { Decay incidence } \\
(\%)\end{array}$} & \multirow{2}{*}{ Mean } & \multicolumn{2}{|c|}{$\begin{array}{c}\text { Decay severity } \\
(0-3)^{* * *}\end{array}$} & \multirow{2}{*}{ Mear } \\
\hline & $\begin{array}{l}\text { Without } \\
\text { puncture }\end{array}$ & $\begin{array}{l}\text { With } \\
\text { puncture }\end{array}$ & & $\begin{array}{l}\text { Without } \\
\text { puncture }\end{array}$ & $\begin{array}{l}\text { With } \\
\text { Puncture }\end{array}$ & \\
\hline RH 98\%* & 1.25 & 79.93 & $40.59 a$ & 0.01 & 1.84 & $0.93 \mathrm{a}$ \\
\hline RH 94\%** & 1.87 & 77.52 & $39.70 \mathrm{a}$ & 0.03 & 1.61 & $0.82 \mathrm{a}$ \\
\hline \multirow[t]{2}{*}{ Mean } & $1.56 \mathrm{~B}$ & $78.72 \mathrm{~A}$ & - & $0.02 \mathrm{~B}$ & $1.73 \mathrm{~A}$ & - \\
\hline & \multicolumn{2}{|c|}{$\begin{array}{l}\text { Soluble solids } \\
\left.\text { ( }{ }^{\circ} \text { Brix }\right)\end{array}$} & Mean & \multicolumn{2}{|c|}{$\begin{array}{l}\text { Titratable acidity } \\
\left(\mathrm{mEq} 100 \mathrm{~mL}^{-1}\right)\end{array}$} & Mean \\
\hline RH $98 \%$ & 11.95 & 12.02 & $11.99 \mathrm{a}$ & 3.44 & 3.36 & $3.40 \mathrm{a}$ \\
\hline RH $94 \%$ & 12.10 & 11.65 & $11.87 \mathrm{a}$ & 3.69 & 3.25 & $3.47 \mathrm{a}$ \\
\hline Mean & $12.02 \mathrm{~A}$ & $11.83 \mathrm{~A}$ & - & $3.56 \mathrm{~A}$ & $3.30 \mathrm{~B}$ & - \\
\hline
\end{tabular}

* $98( \pm 1 \%)$ = High Relative Humidity $(\mathrm{HRH}) * * 94( \pm 1 \%)=$ Low Relative Humidity (LRH). Means followed by equal letter, lower case in the columns and uppercase in the lines, do not differ by Tukey test, at $5 \%$ of error probability. $* * * 0-3: 0=0 \%$ of the fruit area with decay; $1=0$ up to $30 \%$ of the fruit area with decay; $2=30$ up to $70 \%$ of the fruit area with decay; $3=70$ up to $100 \%$ of the fruit area with decay.

Wounded fruits showed higher decay incidence and higher decay severity (Table 4), that may be explain the higher mass loss of these fruits, especially fruits stored in HRH. This fact implicate that wounded fruits have high post storage losses. According Brackmann et al. (2007) and Brackmann et al. (2008) the decay incidence is increased when fruits are stored under HRH. However, on the present study, independently of the relative humidity, wounded fruits showed higher susceptibility to pathogen. Probably, the higher decay incidence increased the metabolic reaction that reduced the organic acids and so fungal resistance. On the other hand, when LRH could not control decay incidence in wounded fruits, it resulted in fruits with higher flesh firmness (Table 3), corroborating some early researches (BRACKMANN et al., 2007; WEBER et al., 2012).

\section{CONCLUSIONS}


The LRH is not an efficient method to control decay incidence in wounded fruits, but maintain higher flesh firmness, lower ethylene production and respiration rate.

Wounded fruits should be not stored and commercialized as fast as possible, in reason of the high decay incidence and severity during postharvest.

\section{ACKNOWLEDGEMENTS}

To Conselho Nacional de Desenvolvimento Científico e Tecnológico, Coordenação de aperfeiçoamento de Pessoal e de Nível Superior and Fundação de Amparo à Pesquisa do Estado do Rio Grande do Sul, for financial support.

RESUMO: Objetivou-se neste trabalho controlar a ocorrência de podridões e o amadurecimento de frutos com ferimentos pelo manejo da umidade relativa (UR) durante o armazenamento. Os frutos foram acondicionados em minicâmaras experimentais na temperatura de $1{ }^{\circ} \mathrm{C}$ durante um período de cinco meses. Observou-se uma interação significativa para produção de etileno aos dois e seis dias de exposição a $20^{\circ} \mathrm{C}$. Na análise aos seis dias, frutos com ferimento em baixa umidade relativa (BUR) apresentaram menor produção de etileno. Houve maior perda de massa em frutos com ferimento em alta UR. Frutos com ferimento apresentaram elevados índices de podridão. O uso de BUR não é eficiente no controle de podridões em frutos com ferimentos, porém ela mantém maior firmeza de polpa, menor produção de etileno e taxa respiratória. Etileno.

PALAVRAS-CHAVE: Malus domestica. Severidade de podridão. Desordens fisiológicas. Perda de massa.

\section{REFERENCES}

ALVES, E. O.; AMARANTE, C. V. T.; WEBER, A.; MIQUELOTO, A.; BRACKMANN, A. Armazenamento refrigerado de ameixas 'Laetitia' com uso de 1-MCP e indução de perda de massa fresca. Ciência Rural, Santa Maria, v. 40, n. 1, p. 30-36, 2009. http://dx.doi.org/10.1590/S0103-84782009005000251

ALVES, E. O.; STEFFENS, C. A.; AMARANTE, C. V. T.; HENDGES, M. V.; ZANARDI, O. Z.;

MIQUELOTO, A.; SILVEIRA, J. P. G.; BRACKMANN, A. Amadurecimento de kiwis 'Bruno' submetidos ao dano mecânico de impacto e ao tratamento com 1-metilciclopropeno. Bragantia, Campinas, v. 69, n. 3, p. 753 758, 2010. http://dx.doi.org/10.1590/S0006-87052010000300029

BERTON, O. Incidência de podridão amarga em macieira e sua relação com danos de mosca-das-frutas.

CAPTAR, Aveiro, v. 2, n. 3, p. 2-5, 2010.

BRACKMANN, A.; PINTO, J. A. V.; WEBER, A.; NEUWALD, D. A.; STEFFENS, C. A. Indução da perda de massa fresca e ocorrência de distúrbios fisiológicos em maçãs 'Royal Gala' durante o armazenamento em atmosfera controlada. Revista Brasileira de Armazenamento, Viçosa, v. 32, n. 2, p. 87-92, 2007.

BRACKMANN, A.; PETERLE, M. E.; PINTO, J. A. V.; WEBER, A.; SAUTTER C. K.; EISERMANN, A. C. Temperatura e umidade relativa na qualidade da tangerina 'Montenegrina' armazenada. Ciência Rural, Santa Maria v. 38, n. 2, p. 340-344, 2008. http://dx.doi.org/10.1590/S0103-84782008000200007

BRACKMANN, A.; GASPERIN, A. R.; WEBER, A.; ANESE, R. O. Condições de temperatura, umidade relativa e atmosfera controlada para o armazenamento de cebolas da cultivar 'Crioula'. Ciência Rural, Santa Maria, v. 40, n. 8, p. 1709-1713, 2010. http://dx.doi.org/10.1590/S0103-84782010000800006

DURIGAN, M. F. B.; MATTIUZ, B.; DURIGAN, J. F. Injúrias mecânicas na qualidade pós-colheita de lima ácida 'Tahiti' armazenada sob condições ambiente. Revista Brasileira de Fruticultura, Viçosa, v. 27, n. 3, p. 369-372, 2005. 
MATTIUZ, B.; DURIGAN, J. F. Efeito de injúrias mecânicas no processo respiratório e nos parâmetros químicos de goiabas 'Paluma' e 'Pedro Sato'. Revista Brasileira de Fruticultura, Viçosa, v. 23, n. 2, p. 282287, 2001.

MONTERO, S. C. R.; SANTOS, L. C. S.; ANDREAZZA, C. S.; BENDER, R. J.; Influência do dano mecânico de impacto e compressão sobre a respiração de maçãs cultivares Fuji Suprema e Royal Gala. Semina: Ciências Agrárias, Londrina, v. 31, p. 967-974, 2010. http://dx.doi.org/10.5433/1679-0359.2010v31n4p967

MORETTI, C. L. Injúria interna de impacto em frutos de tomate: fisiologia e conservação pós-colheita. Tese (Doutorado em Produção Vegetal), Viçosa, 1998. 132 p. Universidade Federal de Viçosa.

PAYASIL, A.; MISHRA, N. N.; CHAVES, A. L. S.; SINGH, R. Biochemistry of fruit softening: an overview. Physiology and Molecular Biology of Plants, v. 15, n. 2, p. 103-113, 2009.

http://dx.doi.org/10.1007/s12298-009-0012-z

STEFFENS, C. A.; ESPINDOLA, B. P.; AMARANTE, C. V. T. A.; SILVEIRA, J. P. G.; CHECHI, R.;

BRACKMANN, A. Respiração, produção de etileno e qualidade de maçãs 'Gala' submetidas ao dano mecânico e tratadas com 1-metilciclopropeno. Ciência Rural, Santa Maria, v. 38, n. 7, p. 1864-1870, 2008.

http://dx.doi.org/10.1590/S0103-84782008000700010

WEBER, A.; BRACKMANN, A. THEWES, F. R; BOTH, V.; ANESE, R. O.; SCHORR, M. R. W. Relative humidity and its interaction with the storage temperature of 'Gala' apples and mutants. Ciência Rural, Santa Maria, v. 42, n. 12, p. 2159-2165, 2012. http://dx.doi.org/10.1590/S0103-84782012001200009 